\title{
Rainfall thresholds for the occurrence of shallow landslides determined for slopes in the Nowy Wiśnicz Foothills (Polish Flysch Carpathians)
}

\author{
Piotr DEMCZUK², Tymoteusz ZYDROŃ ${ }^{1, *}$ and Marcin SIŁUCH ${ }^{2}$ \\ 1 University of Agriculture, Department of Hydraulic Engineering and Geotechnics, al. A. Mickiewicza 24/28, 30-059 \\ Kraków, Poland \\ 2 Maria Curie-Skłodowska University, Faculty of Earth Sciences and Spatial Management, al. Kraśnicka 2cd, 20-718 Lublin, \\ Poland
}

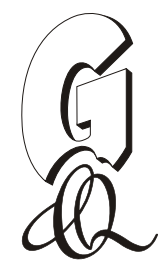

Demczuk, P., Zydroń, T., Siłuch, M., 2019. Rainfall thresholds for the occurrence of shallow landslides determined for slopes in the Nowy Wiśnicz Foothills (Polish Flysch Carpathians). Geological Quarterly, 63 (4): 822-838, doi: 10.7306/gq.1504

\begin{abstract}
Values of rainfall thresholds on selected shallow landslide slopes (Dział, Gwoździec) located in the Nowy Wiśnicz Foothills are determined using a physically-based slope stability model considering a long-term period of analysis (GeoSlope Inc software). Slope stability analysis included determination of the impact of rainfall on changes of stress state within the soil substrate and their influence on estimation of mass movement risk. The slope stability calculation results have shown that the rainfall threshold values are a function of many variables, primarily the hydraulic properties of soil and rock substratum, temporal distribution of precipitation, and soil moisture content conditions in the period proceeding rainfall. The results of the calculations indicate that, in extreme cases, accumulated rainfall threshold values for the same slope can range from $\sim 100$ to $500 \mathrm{~mm}$. Estimated rainfall threshold values were lower than those values reported in the literature for the Polish Carpathians, but are similar to those determined by Guzetti et al. (2007) for Central and Southern Europe.
\end{abstract}

Key words: landslide, slope stability, rainfall threshold, VADOSE/W, SLOPE/W, Polish Flysch Carpathians.

\section{INTRODUCTION}

Mass movements are one of the main factors contributing to transformation of terrain in mountainous areas. In Poland, the region of the Outer Carpathians (the so-called Flysch Carpathians) is notably exposed to this type of process, as its terrain features and complex geological structure promote landslides. Periods of intensification and activation of mass movements in the Carpathians are mostly associated with periods of precipitation (Starkel, 1960; Jakubowski, 1964; Gil, 1997; German, 1998; Poprawa and Rączkowski, 1998, 2003; Gorczyca, 2000, 2002, 2008; Lach and Lewik, 2002; Lach, 2004; Długosz, 2009; Bodziony and Baziak, 2007; Bucała, 2009, 2012), but also with lateral river erosion (Klimaszewski, 1935; Ziętara, 1968; Kotarba, 1986; Gorczyca, 2004), headward erosion (Starkel, 1960; Margielewski, 1994), the increased weight of slope soil via over-saturation with rainwater (Kleczkowski, 1955; Starkel, 1960; Jakubowski, 1968; Gil, 1997; Margielewski, 2002; Rączkowski and Mrozek, 2002), and seismic activity (Sawicki, 1917; Kleczkowski, 1955; Gerlach, 1958; Starkel, 1960; Jakubowski, 1968; Bajgier, 1993; Schenk et al., 2001). Most research into mass-movement processes is fo-

* Corresponding author, e-mail: tymoteusz.zydron@urk.edu.pl Received: January 21, 2019; accepted: October 3, 2019; first published online: December 20, 2019 cused on determination of the magnitude of rainfall thresholds that initiate these processes. In general, there are two groups of methods for determination of rainfall threshold values. One group comprises empirical methods (e.g., Caine, 1980; Glade et al., 2000; Guzetti et al., 2007; Brunetti et al., 2010) related to observations of actual events in regions where mass movements have occurred. The other group consists of model calculations taking into account physical processes in the soil substrate which lead to perturbation of the slope limit equilibrium. Typically, these methods involve the use of a simplified calculation model for spatial analysis in GIS (Pack et al., 1999; Crosta and Frattini, 2003; Baum et al., 2005; Zizioli et al., 2013), in which the slide plane is assumed to be a planar surface (translational landslide) parallel to the ground surface. The basic problem in the application of deterministic methods lies in the usually limited data on the engineering-geological conditions in any given basin.

Determination of the magnitude of the rainfall threshold is a complex task (Gil, 1997; Gil and Długosz, 2006; Guzzetii et al., 2007), as it depends both on the properties of the engineering-geological materials present on slopes and their lithological conditions, and on the intensity and duration of precipitation. The basic method for reduction of the effects of mass movements is monitoring the process, e.g. by an automatic control system. A prototype of such a system is being used in Szymbark near Gorlice (Polish Flysch Carpathians) (Bednarczyk, 2010, 2018) for continuous measurements of displacements of inclinometer columns. This type of measurement system is expensive and its large-scale use is therefore often 
limited due to the complex (varied) structure of the area being analysed. It seems that meteorological monitoring is potentially a relatively cost-efficient indicator of landslide hazards, as monitoring data in combination with knowledge of the geological structure and adequate engineering tools (models of the soil and rock substrate) can greatly contribute to identification of the magnitude of rainfall that can pose a threat to slope stability. Calculation programs, which include the physical description of changes in the stress state in the soil substrate, are widely used tools for assessment of slope stability conditions (Rahardjo et al., 2007, 2010; Tsai, 2008; Tsai et al., 2008; Zabuski et al., 2009; Tsai and Wang, 2011; Rahimi et al., 2011; Ukleja, 2016). Such programs consider static models of slope or take into account only the impact of rainfall on slope stability conditions but disregard the role of other meteorological factors e.g. air and soil temperature, air humidity, wind velocity.

This study determines the threshold values of cumulative rainfall sums triggering processes that lead to reduction of the stability of selected shallow landslide slopes located in the area of the Wiśnicz Foothills. The calculation method applied is developed from typical stability analysis and allows determination of the impact of a number of meteorological factors (not only precipitation) on the distribution of rainwater within a slope.

\section{STUDY AREA}

The study area is in the mesoregion of the Wiśnicz Foothills, which lies within a physico-geographical division that comprises the eastern part of the higher-level region - the West Beskid Foothills (Kondracki, 2009). Classified geomorphologically, (Klimaszewski, 1972), it forms the eastern part of the Wieliczka Foothills.

In terms of geological structure, the study area is located within two tectonic units: the Carpathian Foredeep and the Outer Carpathians (Oszczypko et al., 2008). The main tectonic units of the Wiśnicz Foothills are: the Skole Unit, the Subsilesian Unit, the Silesian Unit, the Magura Unit and the Neogene formations of the Carpathian Foredeep.

The youngest lithostratigraphic formations are Quaternary deposits with a thickness of a few to several metres. They result from the South Polish Glaciation and Central Polish (Vistula) Glaciation as well as including Holocene deposits. They are mainly developed as fluvial deposits in valleys, aelian slope deposits, deluvial covers and colluvial slope deposits (Burtan, 1954; Skoczylas-Ciszewska and Burtan, 1954).

Slope sediments are represented by silty, loess-like deposits. These formed as a result of weathering of the Carpathian flysch and aeolian sedimentation of loess during the Vistula Glaciation. It is estimated that the thickness of loess deposits in the northern part of the test area is 3-5 m, whereas the thickness of loess-like units, silts and silty-sandy loams, varies from 2-3 $\mathrm{m}$ to 6-12 $\mathrm{m}$. In the area around Wola Stróska (eastern side of the Dunajec River) the thickness of silt and loess-like loams, lying above layers of sands and diluvial silts, reaches a total of $\sim 30 \mathrm{~m}$ (Zasoński, 1981). According to Alexandrowicz (1991), based on the grain size distribution, sedimentation structure, analysis of heavy metals and mollusc assemblages, the Wiśnicz Foothills succession correlates with the loess profiles of the Rożnów Foothills, being the age equivalent of the younger loess according to Maruszczak $(1985,1991)$.

At the foot of the slopes there are deposits which are the result of denudation processes, ablation, and water-sorting of loess and loess-like covers. Diluvial-solifluction deposits, as well as colluviums formed around the Pleistocene-Holocene transition, and in the Holocene itself, can also be found on the lower part of the slopes (Burtan, 1954). The thickness of a landslide colluvium, formed as clays, loams and clays with rubble, can reach up to $30 \mathrm{~m}$ (SOPO).

The Wiśnicz Foothills is an example of a mature fluvial-denudation relief, consisting of flat upland areas at 350-420 m above sea level. Hummocks and ridges relate to the main tectonic units of the Silesian Unit and the outcrops of more resistant rocks. The Silesian Unit rocks form large synclines that orographically divide the Foothills into two close-set ranges of lowland foothills (relative altitude of 40-100 m above the bottom of the valleys) and medium foothills (relative altitude of 120-250 above the valley bottoms). The foothill level, in both types of foothill, cuts and levels ridges built of less resistant flysch strata. This level dates back to the Early Pliocene and developed in a cold and dry climate. In bigger valleys one can find a valley level, cut to $40-60 \mathrm{~m}$ in relation to the bottom of modern river valleys. It consists of almost flat surfaces with a slope that is not always consistent with the direction of the valleys, but is always inclined towards their axis. This level dates back to the early Pleistocene (Starkel, 1972).

One of the slopes studied as part of the field and laboratory tests is in Dział, in the western part of the Wiśnicz Foothills (Raciechowice commune; Fig. 1A, B). The region where this slope is located is one of the most landslide-prone areas in the Wiśnicz Foothills. The landslide in Dział forms a straight slope with a clear offset and a steep descent to the valley. The average inclination of the entire slope can be estimated at $\sim 10^{\circ}$, however, at the bottom of the slope it reaches a maximum of $48^{\circ}$. It is a south-east-facing slope, the middle part which is used as pasture, with no traces of agrotechnical operations. The lower part of the slope - the valley slope - is overgrown with bushes and trees up to $20 \mathrm{~cm}$ in diameter. The roots of these plants reach up to $\sim 70 \mathrm{~cm}$ below ground level. The bottom of the river valley is $\sim 4-5 \mathrm{~m}$ wide. There are no traces of lateral erosion caused by water flowing through the riverbed. Within the slope examined there are no signs of water stagnation or exudation. In the elevation profile of the lower part of the slope there is a fault, about $1 \mathrm{~m}$ high, formed after a set of Quaternary slope covers broke off and slid. The colluvial packet rotated by only $\sim 10^{\circ}$ and rested on the unharmed part of the slope. At present, the slope has been additionally supported by this rotated colluvial packet. The landslide does not threaten any infrastructure, and there are no visible traces of undercutting of the lower part of the colluvial packet by the water flowing in the stream. The landslide was classified a rotational slide that occurred within the slope covers without any contact with the bedrock.

The second test object is a straight slope in Gwoździec (Zakliczyn commune), with a constant inclination along its entire length. From the top to the bottom of the valley, the slope is $\sim 340 \mathrm{~m}$ long, and the height difference between the bottom and the top is $60 \mathrm{~m}$. The average inclination of the slope is $12^{\circ}$. The extension of the slope is a floodplain terrace which is $55 \mathrm{~m}$ wide. The slope in Gwoździec is north-facing (Fig. 1A, C) and, during the tests, was overgrown with meadow vegetation. There were no visible traces of water stagnation or exudation. The landslide occurred in the central part of the slope, at $170 \mathrm{~m}$ in the height profile. The length of this landslide is $\sim 60 \mathrm{~m}$ and the width is $\sim 10 \mathrm{~m}$. It is a translational landslide, its maximum thickness being $\sim 2 \mathrm{~m}$. The height of the landslide is $\sim 1.2 \mathrm{~m}$. Currently, the upper part is overgrown with bushes and the landslide does not threaten any infrastructure.

Importantly, the landslides on both slopes occurred at the same time, i.e. in May 2010, when the monthly precipitation totals recorded in the Łazy station exceeded $330 \mathrm{~mm}$ and the maximum daily value noted on May 16 was $110 \mathrm{~mm}$. The data 


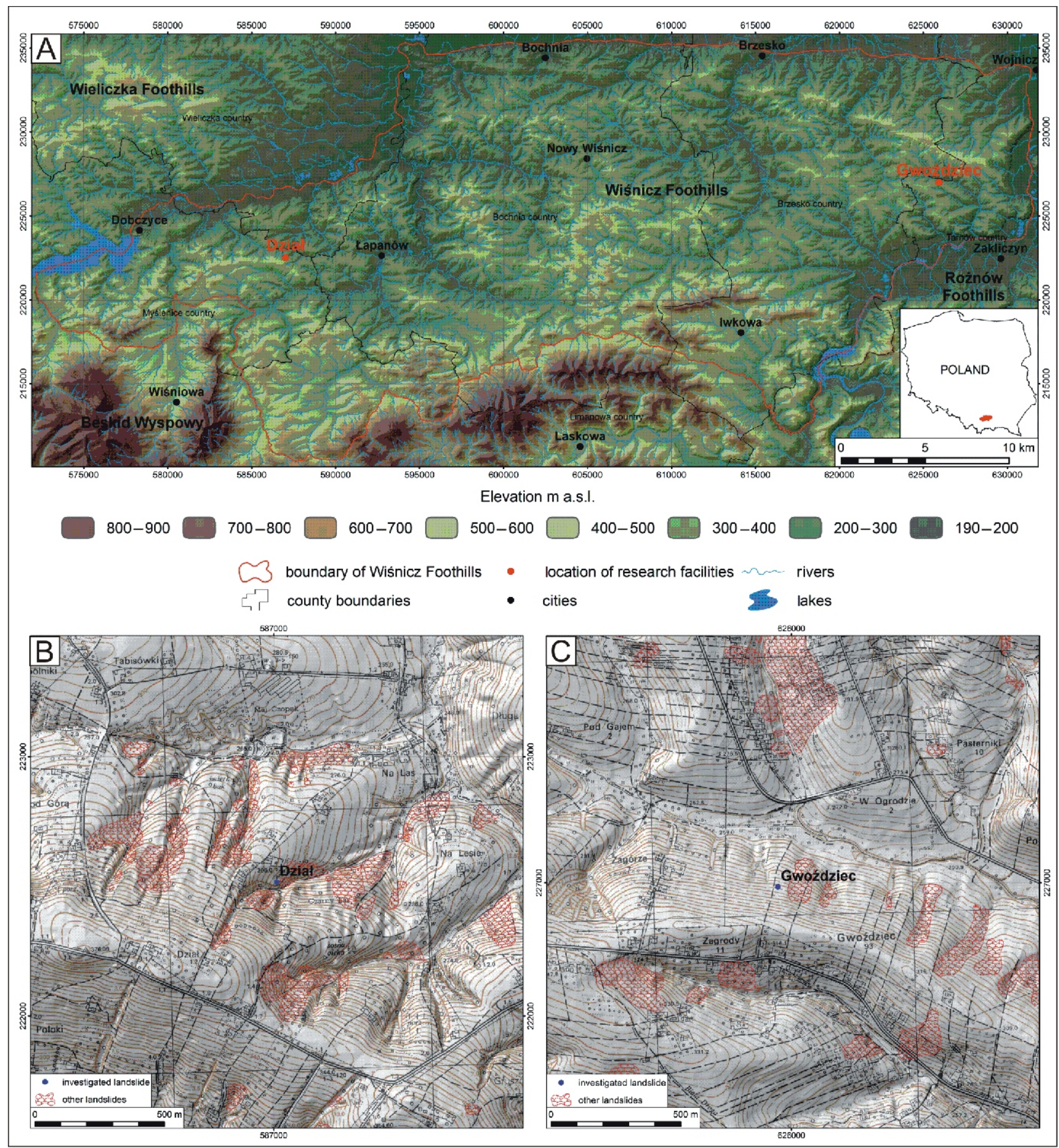

Fig. 1. Location of research facilities in the Wiśnickie Foothills (A) and the context of current landslide forms (B, C - source SOPO database)

SOPO - nationwide project involving landslide inventory in Poland implemented by the Polish Geological Institute (Boratyn et al., 2009; Jurys et al., 2011) 
presented by Woźniak (2011) indicate that the rainfall in May 2010 was substantially greater (even five-fold in an extreme case) than the multi-year average of 1881 to 2010 .

\section{MATERIAL AND METHODS}

The research included field investigations, laboratory tests and slope stability calculations.

Field measurements comprised tacheometric surveying, drilling and collection of undisturbed soil samples. Boreholes were drilled to the depth of bedrock at characteristic points of the slopes, with at least five such soil profiles for each slope analysed.

Soil parameters were determined in the field (soil moisture content, density) and by laboratory tests (Atterberg's limits, permeability coefficients and effective shear strength parameters). The permeability coefficients and shear strength parameters were determined based on triaxial tests. The traxial tests comprised multi-stage consolidated isotropic undrained tests and a sample saturation was done using the back-pressure technique.

Based on meteorological data provided by the Łazy Research Station of the Institute of Geography and Spatial Management, Jagiellonian University, taking into account the lithological composition of the slopes analysed and the values of geotechnical parameters determined from laboratory tests, calculations of slope stability were made for the period 2004-2013. The calculations yielded the range of pore pressure changes in the period analysed, which facilitated determination of extreme slope stability conditions prevailing during the vegetation seasons in the years analysed. It was assumed in the study that the safety factor was equivalent to the distribution of pore water pressure in the soil, which is a derivative of soil moisture content.

The next stage consisted of analysis of the daily precipitation sums obtained from the meteorological stations and posts across the area of the Wiśnicz Foothills (Dział and Gwoździec). In order to ensure representativeness, only data from stations that had been continually measuring precipitation during the vegetation period for over 30 years were analysed. The average onset and end of the vegetation period were determined based on satellite data (MCD12Q2) from the area analysed. The respective beginning and end dates of the growing season in the Foothills were estimated at day 88 and 304 of the year. Daily precipitation sums were used for developing "accumulated rainfall-rainfall duration" curves for various probabilities of precipitation occurrence and duration. Given the relatively long rainfall sequences characterising each station, the probability of rainfall occurrence was estimated at 1, 2, 10, 20, 50 and 99\%. The magnitude of the probability intervals was determined with the Gumbel method based on the distribution of extreme value type I (Otop, 2004). This method is recommended by the WMO for analysis of rainfall sequences.

Calculations of extreme rainfall were performed for 1-, 5-, $10-, 20-, 50-, 100-$ and $120-$ day intervals of daily totals. The totals of these periods were calculated as sums from the antecedent period of the time interval analysed.

Further investigations were focused on determination of changes in slope stability conditions induced in response to 120-day long rainfalls with increasing, constant, and decreasing intensities characterised by a 1-99\% probability of occurrence. For the analysis, three variants of pore water pressure distribution within the slope were employed. Two of these corresponded to the maximum (antecedent wet period) and minimum (antecedent dry period) pore water pressure values at the beginning of the vegetation seasons in 2004-2013. This assumption facilitated determination of changes in slope stability in the period between late March and late July, which substantially coincides with periods of intensification of mass movements in the Polish Flysch Carpathians (Gorczyca, 2004). The third calculation variant corresponded with the minimum pore water pressure of the slope soils (antecedent extremely dry period) observed during the vegetation season.

The analyses were performed with the calculation modules of the following GeoSlope Inc. package:

- VADOSE/W was used to determine the impact of meteorological conditions on the pore pressure distribution in the slope. The analysis was based on an assumption that meteorological conditions (temperature, air humidity, wind speed, Leaf Area Index) represented the multi-year mean values of the corresponding meteorological elements from the period of 2004-2013,

- SLOPE/W - calculations of stability with the Janbu method (limit equilibrium method).

Slope failure (initiation of landslide process) was interpreted as an event where the factor of safety reached a value equal or below 1.0. For each event the total sum of precipitation occurring up to the day of slope failure was considered as a value of threshold rainfall. For each slope 54 analyses were performed.

In the next step of the investigations, the rainfall totals inducing slope failure were converted in each calculation event into the average rainfall intensity and presented as a rainfall intensity vs. rainfall duration $(I-D)$ function. These data calculated for both slopes were joined and illustrated in one figure and the threshold rainfall line $(I-D)$ was drawn as a lower envelope of the all data illustrated in the figure. The $I-D$ equation is as follows:

$$
I=c+\alpha D^{\beta}
$$

where: I - (mean) rainfall intensity, $D$ - rainfall duration, $c, \alpha, \beta-$ regional parameters $(c \geq 0)$.

The rainfall thresholds obtained in this way were compared with the characteristics of some rainfall thresholds reported in the literature and with the rainfall data.

The scope of tests and generalized work methodology is shown in Figure 2.

\section{RESULTS AND DISCUSSION}

\section{GEOLOGICAL-ENGINEERING CHARACTERISTICS} OF THE SLOPES STUDIED

During the field tests in Dział, 5 boreholes to the bedrock of the Krosno strata (Oligocene), up to a maximum of $5.5 \mathrm{~m}$, were drilled across the slope profile (Fig. 3A). Fragments of shale, overlain by some river deposits and a layer of slope diluvium $(>10 \mathrm{~cm}$ thick) were visible in the stream bed. In the upper part of the slope, the slope covers were only $70 \mathrm{~cm}$ thick. Based on the geological profiles, a humic layer, which reaches $\sim 10 \mathrm{~cm}$ thickness (the depth of the grass root systems), and four basic geotechnical layers were determined.

The field tests in Gwoździec included 6 boreholes in the slope profile, carried out to a depth of 1-1.2 $\mathrm{m}$ in the upper and middle parts of the slope and up to $2.5 \mathrm{~m}$ depth in its lower part (Fig. 3B). Each borehole encountered sandstone rocks of the Sub-Magura and Frydman strata. Sandstone rocks were also visible within the stream riverbed. Based on the grain size distri- 


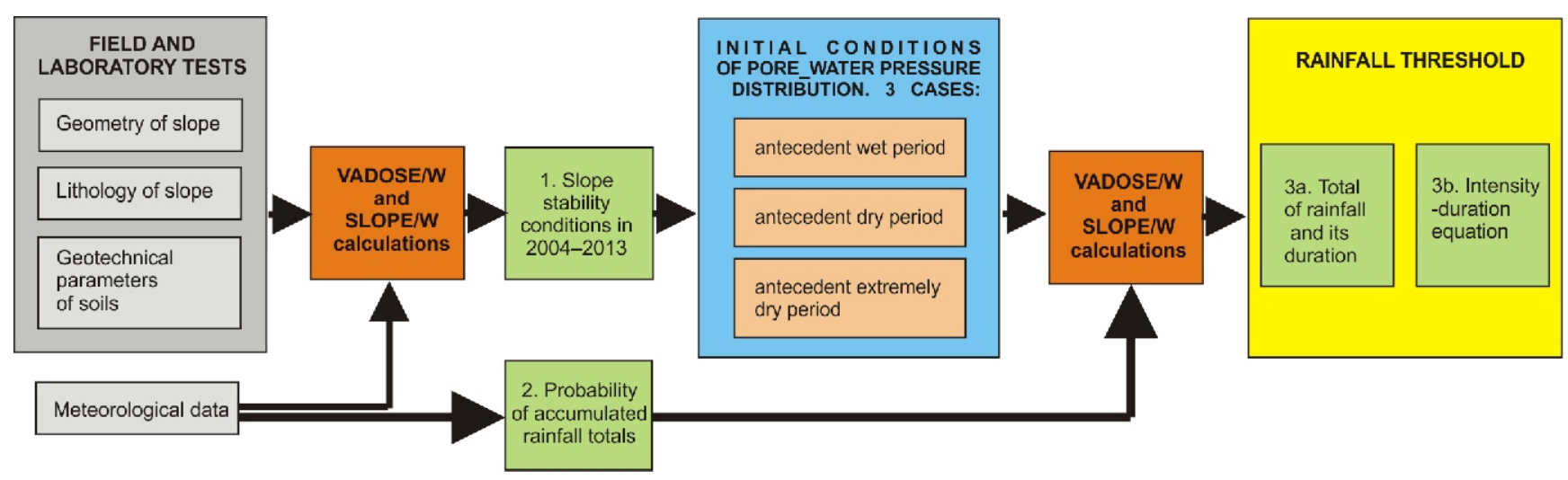

Fig. 2. Research scheme

bution, an uppermost humic layer and four geotechnical layers were distinguished.

Field and laboratory tests revealed that the slopes analysed differ in their lithological structure (Fig. 3) and geotechnical properties (Table 1). On the Dział slope, the substrate comprises mottled clay shales characterized by low permeability, whereas the rock substrate of the Gwoździec slope is built of permeable sandstones. The filtration capacity of the bedrock is reflected by the permeability of the soil layers deposited on the flysch substrate, i.e. the permeability coefficients of the soil on the Gwoździec slope are over two orders of magnitude higher than the values noted for the Dział slope.

\section{ANALYSIS OF STABILITY CONDITIONS ON THE SLOPES} ANALYSED IN 2004-2013

The results of slope stability calculations of both slopes (Fig. 4) support the results of the meteorological observations and demonstrate the most unfavourable stability conditions in May 2010, i.e. the time of the latest landslide disaster in the Polish Flysch Carpathians (Wysokiński, 2011). By contrast, the most favourable slope stability conditions can be noted for August 2007 in the case of the Dział slope and for September
2012 in the case of Gwoździec slope; additionally, high values of the safety factor were obtained for July 2008. Analysis of the calculation results also revealed that, at the beginning of the vegetation period at the end of March, the lowest values of the safety factor occurred in 2010 and the highest values were calculated for 2008 (Dział) or 2012 (Gwoździec). In turn, the highest values of the safety factor in the multi-year period analysed were noted in early July 2008 , with a precipitation rate of $30 \mathrm{~mm}$ in the preceding 40-day period.

\section{STATISTICAL ANALYSIS OF RAINFALL SEQUENCES}

Values of the cumulative maximum rainfall values as a function of the duration and the probability of rainfall occurrence (Fig. 5) recorded by the meteorological station in Łapanów, which is located near the slope at Dział, were considered as representative for further analysis. The calculations yielded only slightly lower maximum daily rainfall values than those reported by Cebulak (1992, 1994), which may be associated with the different periods of data acquisition, i.e. the recent 30 years in the present study and the period of 1951-1980 in the cited paper. For comparison, the analysis of maximum monthly precipitation totals during the period 1951-2005 in the Western Carpathian

Table 1

\section{Geotechnical characteristics of slope soils}

\begin{tabular}{|c|c|c|c|c|c|c|}
\hline $\begin{array}{l}\text { No. of } \\
\text { layer }\end{array}$ & $\begin{array}{l}\text { Type of soil acc. to } \\
\text { PN-EN ISO } 14688-2\end{array}$ & $\begin{array}{l}\text { Plastic limit } \\
\quad[\%]\end{array}$ & $\begin{array}{l}\text { Liquid limit } \\
{[\%]}\end{array}$ & $\begin{array}{c}\text { Coefficient of permeability } \\
{\left[\mathrm{m} \cdot \mathrm{s}^{-1}\right]}\end{array}$ & $\begin{array}{c}\text { Effective angle of internal } \\
\text { friction } \\
{\left[{ }^{\circ}\right]}\end{array}$ & $\begin{array}{c}\text { Effective cohesion } \\
\text { [kPa] }\end{array}$ \\
\hline \multicolumn{7}{|c|}{ Slope in Dział } \\
\hline 1 & $\mathrm{Si}$ & 21.1 & 32.4 & $5.1 \cdot 10^{-8}$ & 30.0 & 0.7 \\
\hline 2 & $\mathrm{clSi}$ & 18.0 & 31.4 & $2.9 \cdot 10^{-8}$ & 27.0 & 6.9 \\
\hline 3 & $\mathrm{clSi}$ & 18.7 & 36.2 & $2.1 \cdot 10^{-9}$ & 34.0 & 3.7 \\
\hline 4 & $\mathrm{clSi}$ & 17.1 & 29.2 & $2.0 \cdot 10^{-9}$ & 32.3 & 5.6 \\
\hline 5 & mottled clay shales & - & - & $1.0 \cdot 10^{-9}$ & - & - \\
\hline \multicolumn{7}{|c|}{ Slope in Gwoździec } \\
\hline 1 & $\mathrm{Si}$ & 19.6 & 26.8 & $5.3 \cdot 10^{-7}$ & 34.4 & 0.0 \\
\hline 2 & $\mathrm{clSi}$ & 19.6 & 31.9 & $8.6 \cdot 10^{-7}$ & 16.6 & 0.5 \\
\hline 3 & sasiCl & 22.8 & 42.7 & $6.9 \cdot 10^{-7}$ & 18.6 & 1.0 \\
\hline 4 & siSa & - & - & $10^{-5}$ & 29.5 & 0.0 \\
\hline 5 & sandstones & - & - & $10^{-6}$ & - & - \\
\hline
\end{tabular}



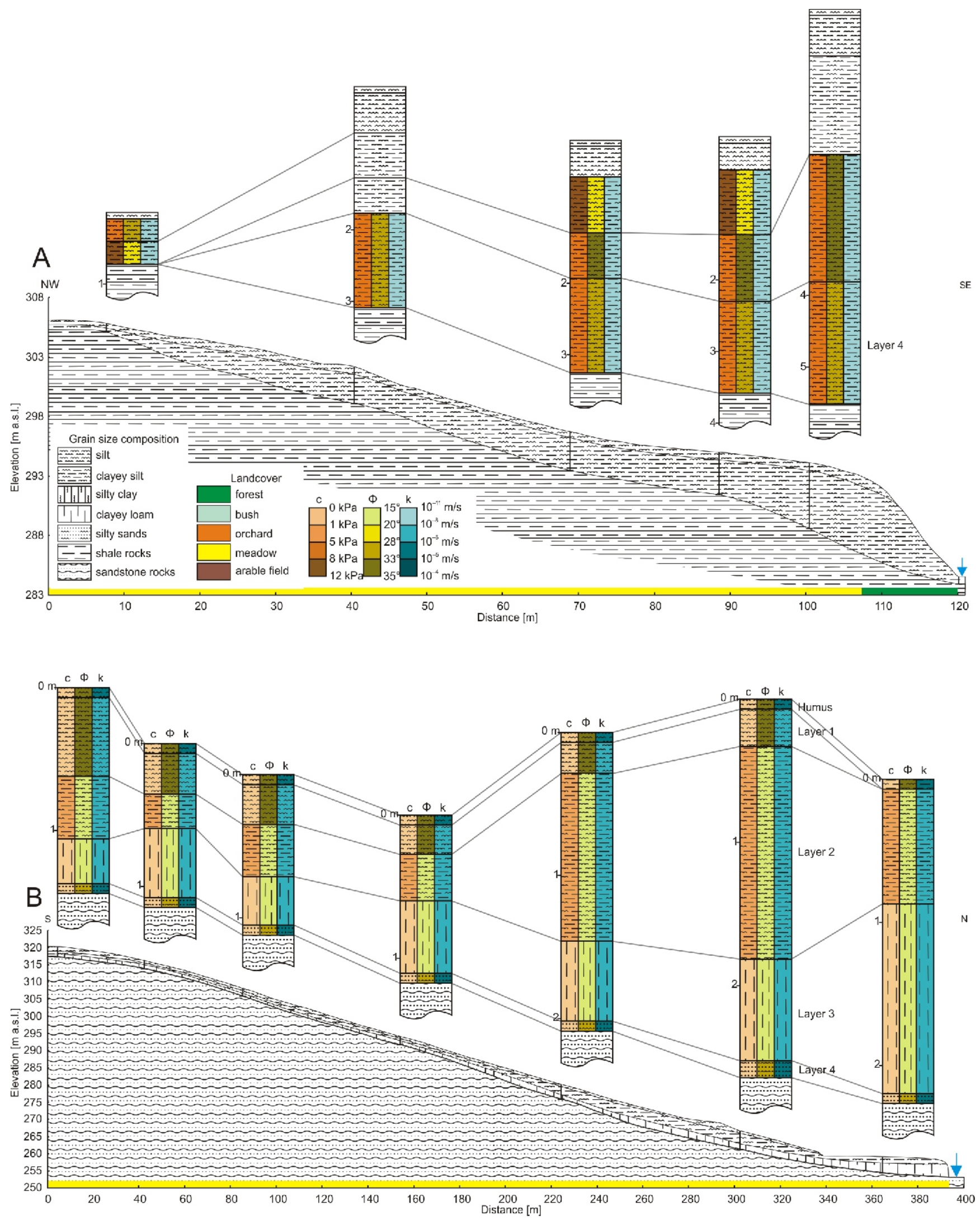

Fig. 3. Geological-engineering profiles of soils deposited on the analysed slopes in Dział (A) and Gwoździec (B) 

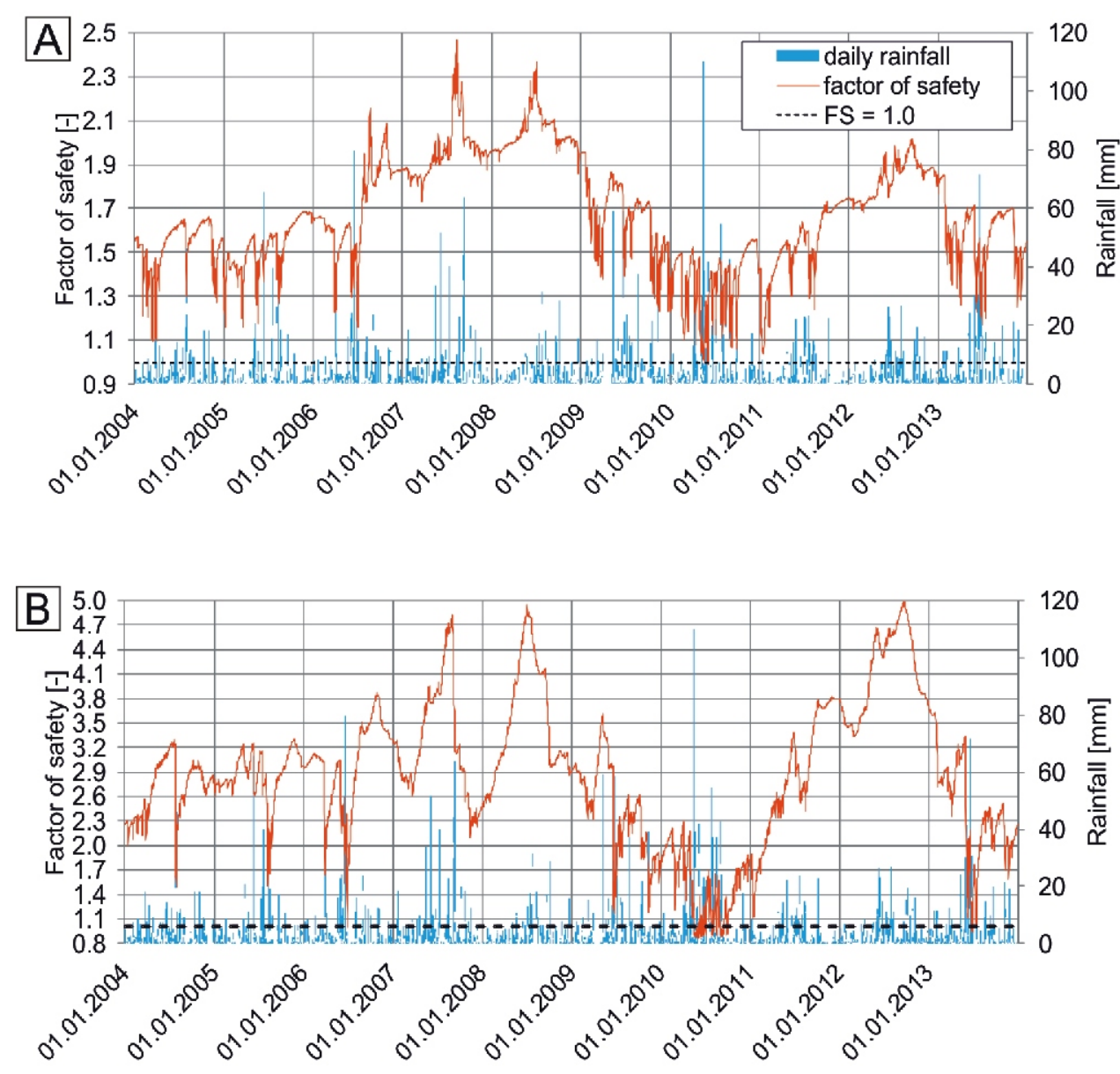

Fig. 4. Calculated results of stability for the Dział (A) and Gwoździec (B) slopes

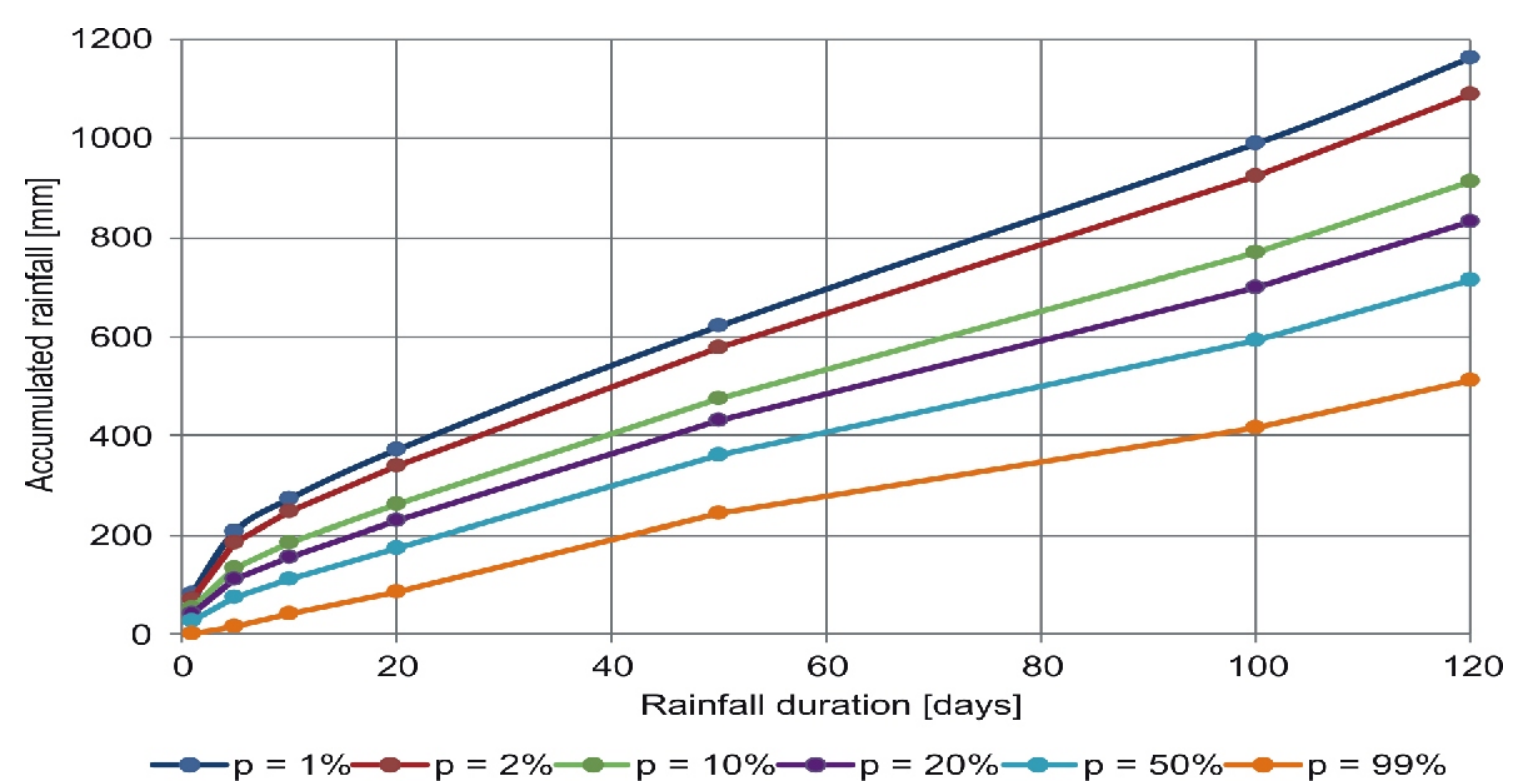

Fig. 5. Probability of accumulated rainfall totals as a function of rainfall duration in the Łapanów 
Mts. in Poland (Cebulska and Twardosz, 2012) indicates that these values ranged from 317 to $512 \mathrm{~mm}$, respectively for Nowy Sącz and Maków Podhalański. These values correspond relatively well to maximum monthly precipitation totals with $1-2 \%$ probabilities of occurrence determined for the area analyzed (see Fig. 5). Besides, mean seasonal sums of atmospheric precipitation in the period of 1951-2010 reported by Czarnecka and Nidzgorska-Lencewicz (2012) for the northern part of Polish Carpathians were 120-140 and $260-280 \mathrm{~mm}$ in spring and summer respectively. Such values are lower than the sum of precipitation determined in this study with $99 \%$ probability of occurrence.

The precipitation totals obtained in this study are slightly lower than the cumulative values presented by Floris et al (2012) for the north-western part of the Italian Alps and higher than the cumulative rainfall rates noted in in the Apennines (Floris and Bozzano, 2008) and the Lisbon region (Vaz et al. 2018). Such differences of the precipitation totals for different regions are related to their geographical location, altitude and local climate. In general, average annual precipitation in the region of the Alps and western Balcans are significantly higher that those in the Carpathians in Poland.

\section{IMPACT OF RAINFALL ON SLOPE STABILITY}

Based on the slope stability calculation results obtained for different rainfall totals and their patterns, it can generally be stated that the response of a slope to rainfall depends on the magnitude (and the associated probability of occurrence) and temporal distribution of precipitation as well as the initial pore water pressure distribution conditions (Fig. 6).

Clearly, the increase in the probability of rainfall occurrence (decreased rainfall frequency) is accompanied by a delayed response to the impulse; in extreme cases, the calculated factors of safety exceed 1.0, indicating that the threat of landslide initiation is not extremely high. Such situations occur when rainfall events are preceded by low pore water pressure levels in the middle of the vegetation period. In such conditions, even high values of precipitation (over $1100 \mathrm{~mm}$ ) in the preceding period of 120 days are not sufficient to induce loss of stability. In turn, at high values of antecedent wetness (early 2010), rainfall causes relatively rapid deterioration of stability conditions, and the length of the period in which critical conditions of slope equilibrium are achieved is clearly associated with the intensity of precipitation, which is particularly evident in the case of the Gwoździec slope.

The time of the slope response to the rainfall impulse depends on the temporal rainfall distribution. It is the shortest in the case of high intensity rainfall events in the initial stage of the rainfall period. Similar results were obtained by Tsai (2008) and Tsai and Wang (2011), performing theoretical calculations using infinite slope analysis. In the cases analysed in this study, the minimum rainfall volume that led to slope failure was 105 and 92 mm for the Dział and Gwoździec slopes, respectively. These data are very similar to the rainfall threshold values reported (Gil and Długosz, 2006) for debris-type landslides in the Outer Carpathians.

Figure 7 shows accumulated rainfall threshold values for both slopes analysed by comparison with accumulated rainfall values with a 1-99\% probability of transgression. The analysis of the relationships generally suggests differences in the response of both slopes to rainfall impulses. Evidently, slope failure is noted after a 3-day rainfall event in an extreme case of the Gwoździec slope and after 11 days of rainfall on the Dział slope. The differences in the response of the slopes to the rainfall are related to their geological structure, primarily to the permeability of the soil and rock substrate. Soils deposited on the Gwoździec slope exhibit clearly higher permeability than the deposits on the Dział slope. Similar relationships were shown by Rahardjo et al. (2007), who analysed e.g. the impact of soil permeability on a slope exposed to simulated intense daily rainfall, on changes in its safety factor. The authors demonstrated that slopes with low permeability were generally resistant to intense short-term rainfall events.

The data shown in Figure 8 show a significant effect of the antecedent soil moisture content conditions on the rainfall threshold values. At high values of profile soil moisture content in the period preceding the rainfall, the minimum rainfall threshold values are $\sim 100 \mathrm{~mm}$ for both slopes, which is similar to the values reported for debris-type landslides (Gil and Długosz, 2006) in the Polish Flysch Carpathians. In turn, when the period that precedes rainfall occurs in the middle of the vegetation season (antecedent extremely dry period), the rainfall threshold values are $\sim 350 \mathrm{~mm}$ for the Gwoździec slope and over $1100 \mathrm{~mm}$ for the Dział slope. It can also be observed that, with increasing rainfall duration, the calculated rainfall threshold values are similar to the curves of accumulated rainfall with an almost $99 \%$ probability. This implies that, in theory, slope failure does not have to be triggered by high rainfall values but rather by the occurrence of continuous rainfall. The analysis of the precipitation data from the first 60 days of the vegetation period in 2004-2013 shows that the accumulated rainfall in 2010 was $376 \mathrm{~mm}$, which corresponds to the cumulative value of rainfall with a $\sim 50 \%$ probability of occurrence. In the other years, the accumulated rainfall values from 60 days did not exceed $150 \mathrm{~mm}$. The discrepancies between the calculated cumulative rainfall values and the results of observations of the beginning of the vegetation period are associated with the fact that the highest rainfall values in Poland are noted in the summer months (Woźniak, 2011), and the rainfall values observed at the beginning of the vegetation period are half of that.

\section{ANALYSIS OF OBTAINED RAINFALL THRESHOLD}

Results of totals and durations of rainfall that caused slope failure were converted into a rainfall intensity-duration function (Fig. 8). Interestingly, a 3-day-long rainfall with intensity slightly higher than $1 \mathrm{~mm} \cdot \mathrm{h}^{-1}$ is sufficient for initiation of failure in the case of the Gwoździec slope. The rainfall depth that leads to slope instability is clearly associated with the initial soil moisture conditions, i.e. the lower the slope soil moisture content, the more precipitation must be accumulated in the profile. In both variants, there is a clear, nearly vertical $I-D$ (rainfall intensity-rainfall duration) correlation. This may indicate that the period preceding the major rainfall is relevant for the stability of this slope, which is consistent with the results of Rahimi et al. (2011), whose calculations showed that slopes covered by low-permeability deposits were more susceptible to antecedent long-term rainfalls.

The rainfall intensity-duration data obtained for both slopes were compared with the characteristics of some rainfall thresholds reported in the literature and with rainfall data reported in different regions in the world (Fig. 9) and extreme rainfall values noted in the Polish Flysch Carpathians, which were reported by German (2000), Gorczyca (2004), Starkel (2006, 2011), Bodziony and Baziak (2007), Bucała (2009) and Długosz (2011; in Fig. 9 described as the Carpathians Mountain). In most cases, the calculated rainfall threshold values for the Nowy Wiśnicz Foothills are lower than those triggering floods and landslides in the Carpathians. These differences may be 
Dział - antecedent wet period

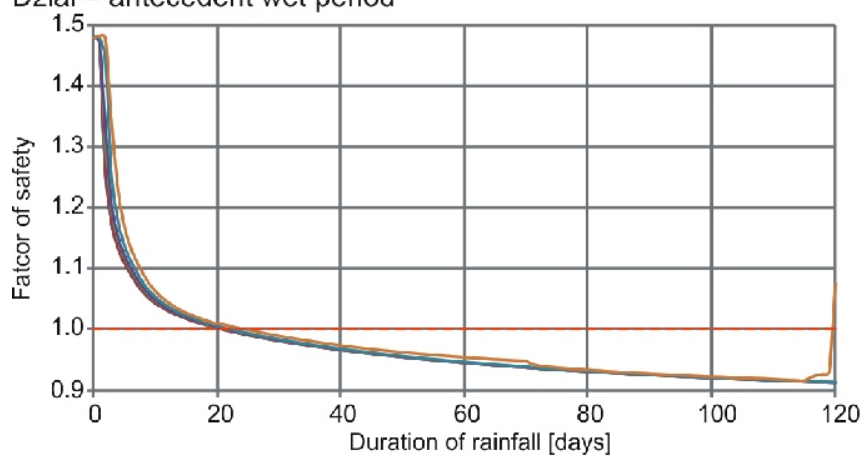

Dział - antecedent dry period

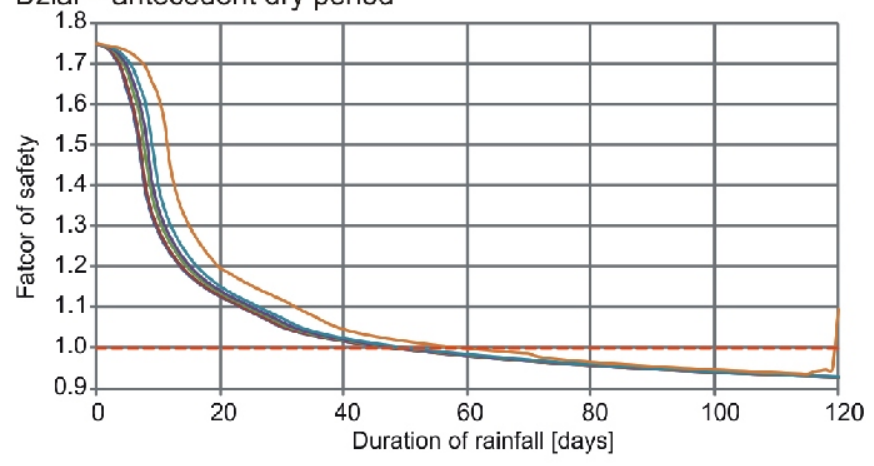

Dział - antecedent extremely dry period

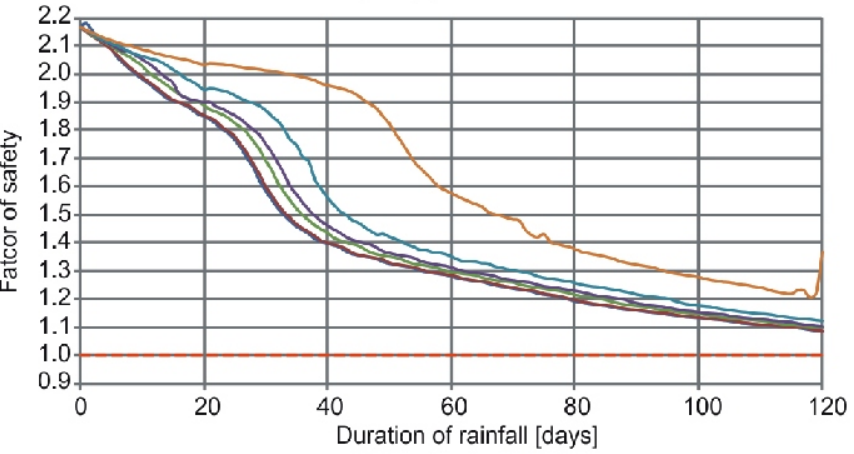

Gwoździec - antecedent wet period

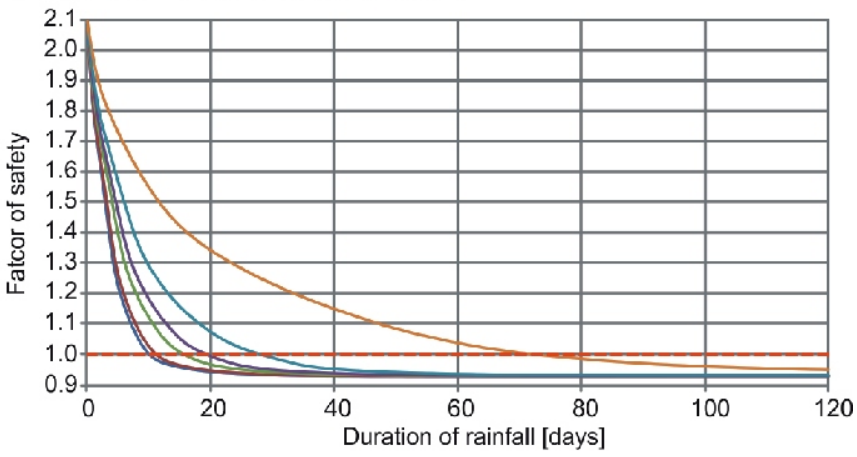

Gwoździec - antecedent dry period

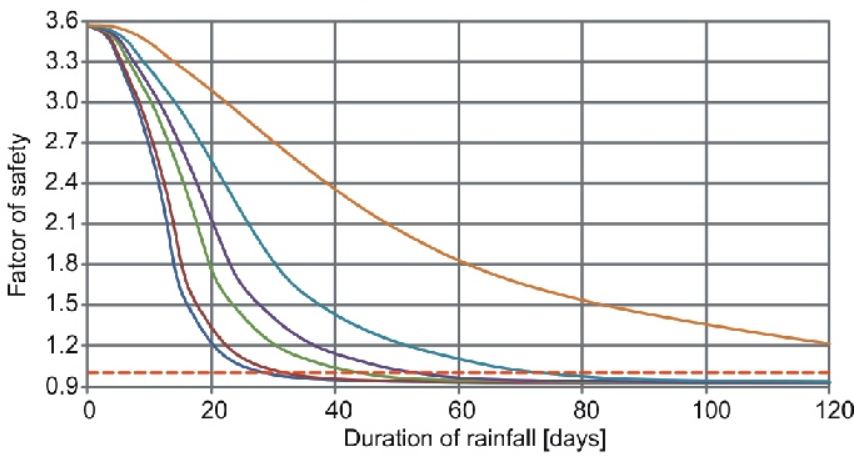

Gwożdziec - antecedent extremely dry period

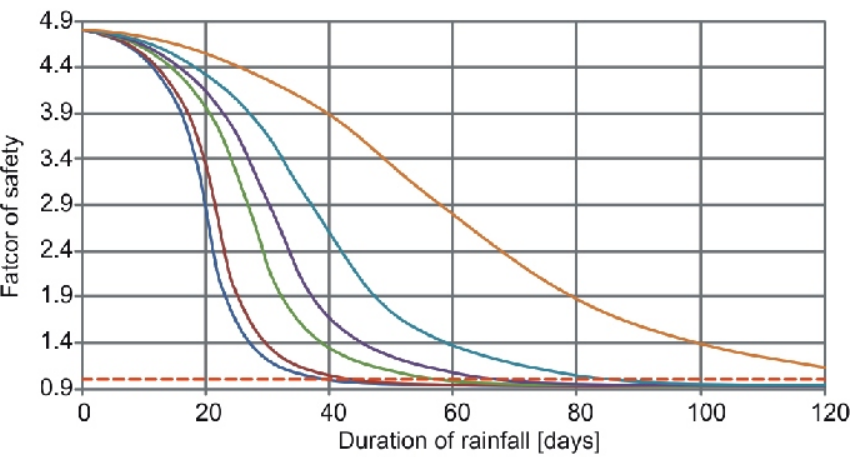

Probability of accumulated rainfall occurrence:

$-1 \%-2 \%-10 \%-20 \%-50 \%-99 \%---$ FS $=1.0$

Fig. 6. Calculated stability of the investigated slopes in relation to the probability of occurrence of accumulated rainfall and initial soil moisture content conditions

caused by two factors. Most importantly, the values reported in the literature often refer to the summer period with evapotranspiration as an important factor of water balance, as it reduces the effective amount of rainwater infiltrating the slope. In the case of the slopes investigated in this study, the analyses included rainfall events occurring at the beginning of the vegetation period when the evapotranspiration process is weak due to low temperatures and low plant water demand. The other cause of the differences between the results of this paper and data reported in the literature may be associated with different methods of interpretating the rainfall threshold values. Most literature focuses on rainfall events initiating slope processes (typically lasting from 1 to 5 days), whereas longer rainfall periods preceding the initiating event are analysed infrequently.

The data presented indicate that the rainfall threshold values obtained for the slopes analysed are very similar to rainfall threshold values suggested for the Central European Adriatic
Danubian South-Eastern Space (CADSES) area (located in Central and Southern Europe), including the Polish Flysch Carpathians, developed by Guzetti et al. (2007) and to the rainfall values provided by Moser and Hohensinn (1983) for Carinthia and East Tyrol in Austria.

The calculated threshold rainfall for the slopes analysed was determined using the following formula:

$$
I=69.9 \cdot D^{-0.93} \text { for } 72 \leq D \leq 600
$$

where: the unit of $/$ is $\mathrm{mm} \cdot \mathrm{h}^{-1}$ and the unit of $D$ is hour.

$I-D$ values for periods longer than 600 hours do not fit within the proposed $I-D$ envelope. For such periods, the inclination of the $I-D$ line is low and for determination of the critical rainfall threshold envelope for the whole period of analysis an asymp- 
A

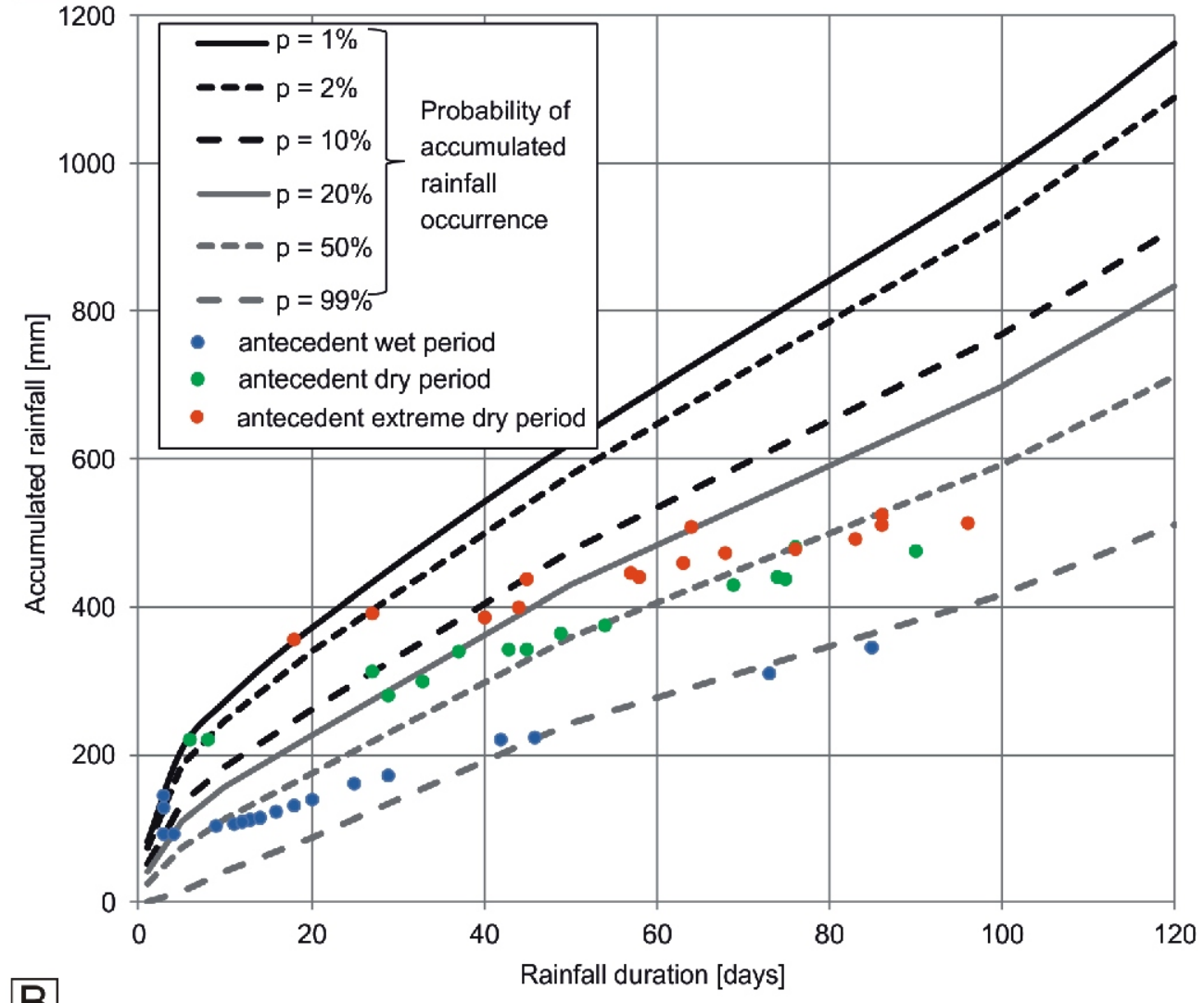

B

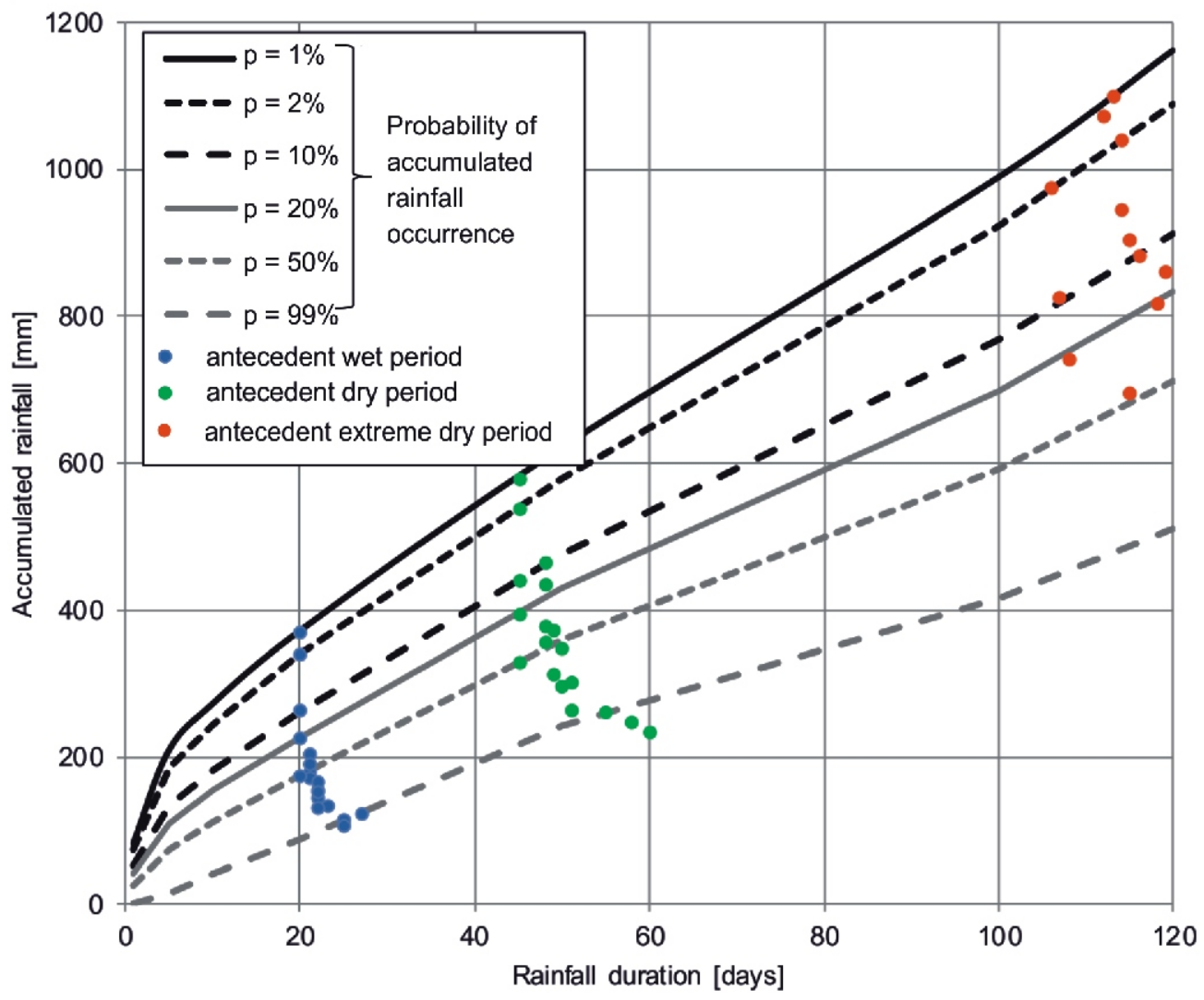

Fig. 7. Rainfall threshold values for the Dział (A) and Gwoździec (B) slopes in relation to the initial wetness conditions 

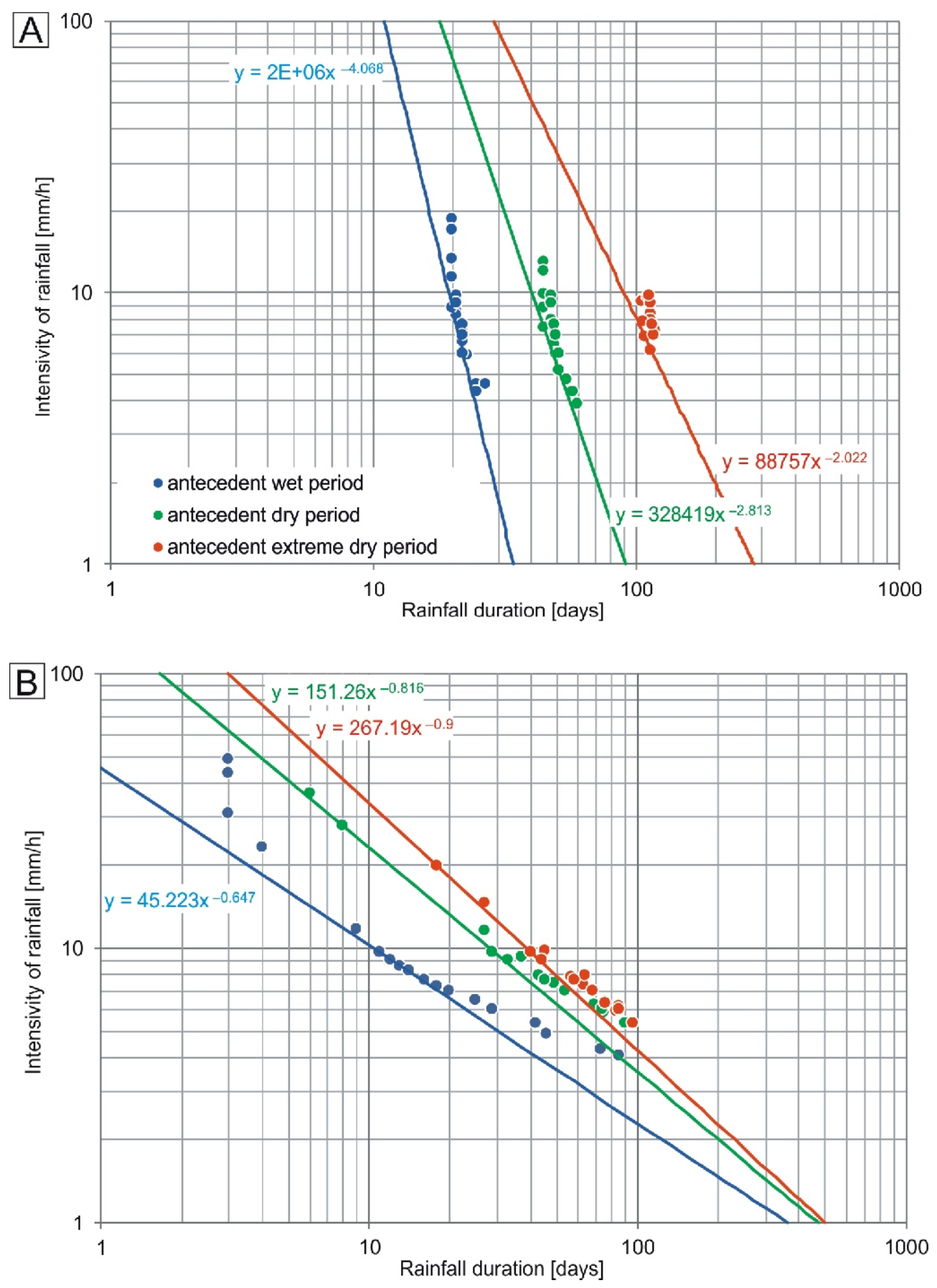

Fig. 8. Relationship between the mean threshold rainfall intensity and rainfall duration and the antecedent wetness conditions on the Dział (A) and Gwoździec (B) slopes 


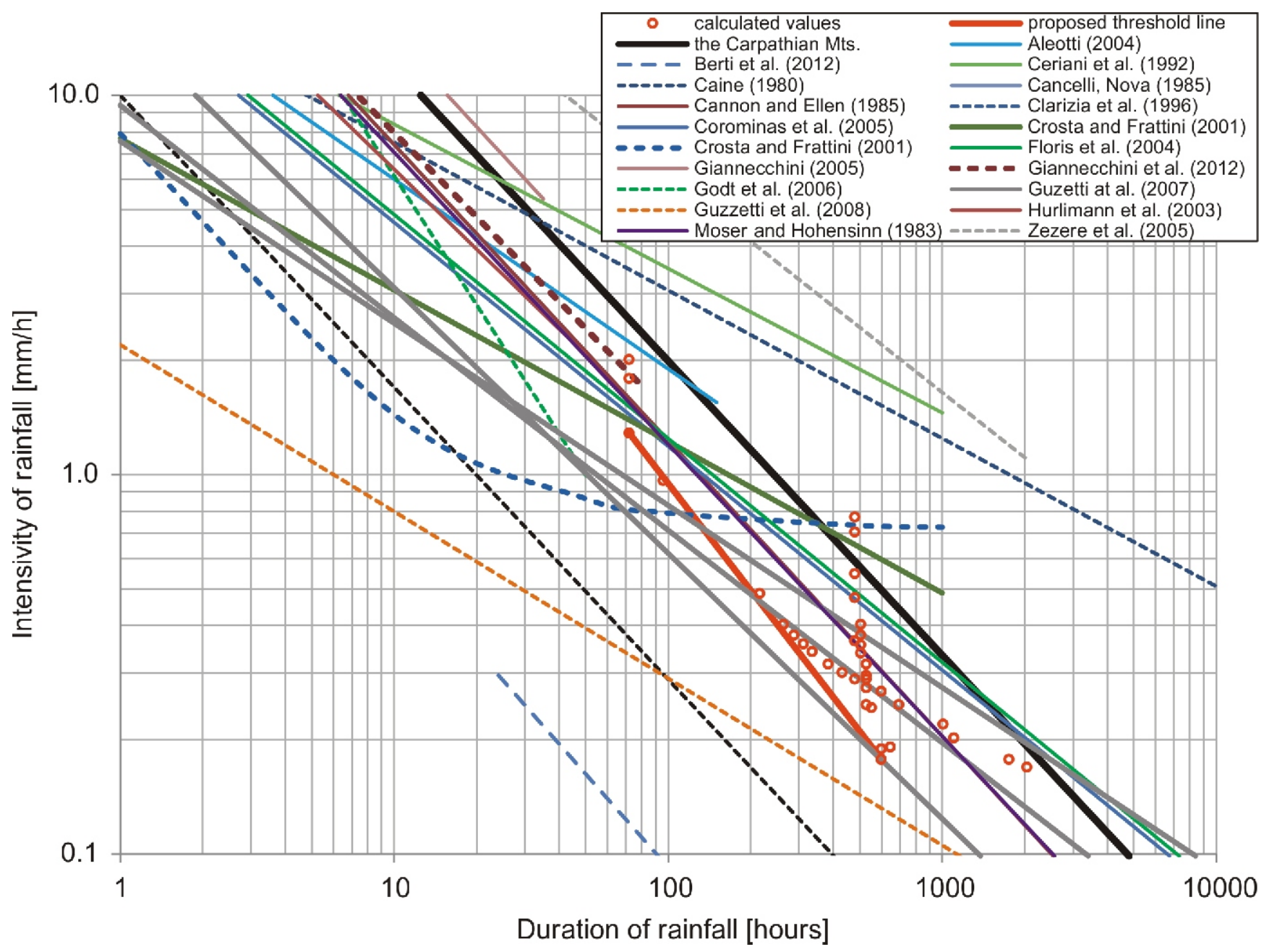

Fig. 9. Comparison of the calculated rainfall threshold values with selected literature data*

* Rainfall threshold for the Polish Carpathian Mountains were determined using the data taken from: Bodziony and Baziak (2007); Bucała (2009, 2012); German (1998); Gil and Długosz (2006); Gorczyca (2000, 2002, 2008); Guzetti et al. (2007, 2008); Hurlimann et al. (2003); Jakubowski (1964); Lach (2004); Lach and Lewik (2002); Poprawa and Rączkowski (1998); Starkel (1960)

totic function is most suitable, as in Wieczorek (1987) and Crosta and Frattini (2001). In the case of the slopes analysed, the range of data is insufficient to estimate the parameters of such a function. These relationships, supported by data from the literature, also indicate that determination of an intensity-duration rainfall threshold for a very long period (over 500 hours) can be challenging. In such situations, slope stability calculations can be a suitable tool in landslide risk management.

Figure 10 shows accumulated rainfall values from 2010 shown in reverse order, i.e. the 110.2-mm rainfall event on May 16 is shown first. Comparison of these data demonstrates a $<1 \%$ probability of occurrence of such rainfall; hence, the geomorphological effects induced by the rainfall were substantial. For comparison, Figure 10 presents the same precipitation data from early 2010 , disregarding the rainfall on May 16 . This was aimed at determining whether the rainfall events in April and May 2010 were statistically high in comparison with the cumulative rainfall curves with $1-99 \%$ probabilities shown in Figure 4. It is evident that the rainfall totals at the beginning of the growing season in 2010 preceding the disastrous rainfall on May 16 were not extremely high in comparison with a typical rainfall pattern $(p=99 \%)$. The amount of the daily rainfall corre- sponded to a $50 \%$ probability of occurrence of maximum precipitation rates only on two days (6-04-2010 - $26.7 \mathrm{~mm}$, $1-05-2010-25.3 \mathrm{~mm}$ ). Therefore, it seems that meteorological conditions, primarily relatively low temperatures compared with those prevailing in the middle of the vegetation season and at the beginning of vegetation growth, were an important factor contributing to increased rainfall infiltration into the soil in this period. Both these factors probably had an impact on the low evapotranspiration rates; hence, a substantial portion of rainfall had accumulated in the slope covers. Figure 10 shows two rainfall events preceding the disastrous rainfall $(\sim 150 \mathrm{~mm})$ on July 9, 2010 near Żegocina (German, 2000) and the rainfall in the Wielka Puszcza catchment on August 24, 2005 ( 125 mm) (Bodziony and Baziak, 2007). In both cases the cumulative rainfall values preceding both these disastrous rainfalls were in the probability range $<50 \%$; hence, the probability of their occurrence was significantly lower than that of the rainfall events in April and May 2010. Both these events occurred in summer, when evapotranspiration rates are higher than at the beginning of the vegetation season. In the light of these data, it seems that the rainfall values that cause saturation of the soil profile differ depending on the period of rainfall occurrence. At the beginning 


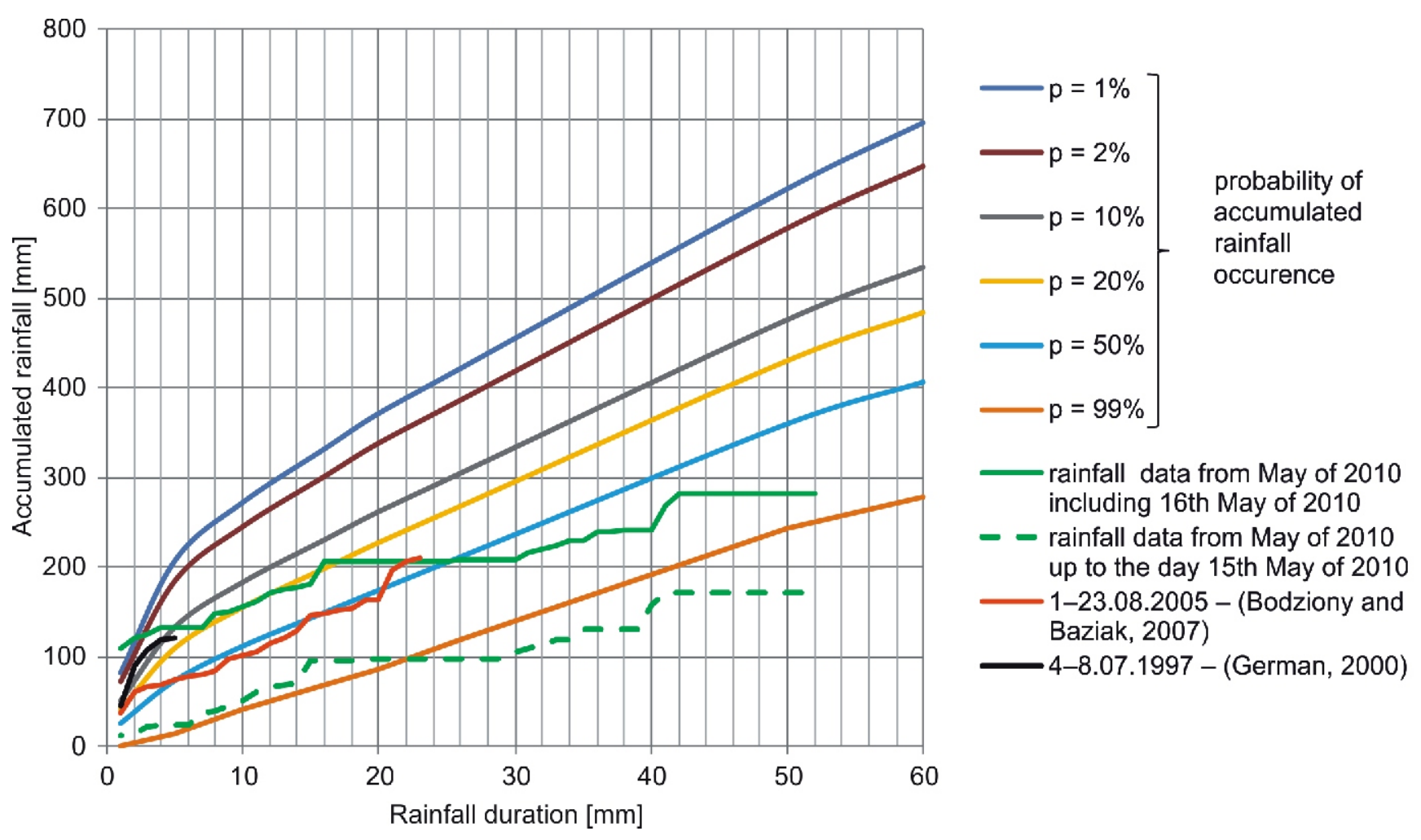

Fig. 10. Curves of the rainfall occurrence probability in light of the events at the beginning of the vegetation period in 2010

of the vegetation period, the volume of rainfall inducing significant changes in soil profile saturation is $\sim 25 \mathrm{~mm}$, which corresponds to a $50 \%$ probability of daily rainfall occurrence. As suggested by Floris and Bozzano (2008) as well as by Floris et al. (2012), this probability can be an indicator of landslide hazards. In turn, the same effect is observed in the middle of the vegetation period (July and August) in the case of a rainfall volume of $\sim 40 \mathrm{~mm}$, which corresponds to a $20 \%$ probability of occurrence. Such rainfall preceded the catastrophic torrential rains from July 9, 1997 and August 24, 2005.

The critical stability conditions in the case of both slopes were achieved at full soil saturation, which in practice means that changes in stability can be correlated with fluctuations in the groundwater table. Figure 11 shows the dependence of safety factor values on the pore pressure values calculated at a site located in the central part of the landslides analysed on the rock substrate. The data indicate relatively good correlation between both parameters, in particular in the range of the positive pore pressure values. The critical pore pressure values of the Dział slope are $\sim 25 \mathrm{kPa}$, whereas the positive pore pressure values yield a safety factor in the range of 1.3-1.4. In the light of requirements of standards for earth-made constructions of lower-class technical, this implies acceptable stability conditions for earth structures. Similar, in the case of the Gwoździec slope, mobilisation of positive pore pressure values occurs at a safety factor of 1.3 , whereas pore pressure values exceeding $30 \mathrm{kPa}$ indicate full saturation of the soil profile. These correlations indicate that observations of the groundwater level are a good indicator of landslide hazards, particularly when the geological structure of the region is of mosaic type, which impacts on the rate of slope response to rainfall impulses.

\section{CONCLUSIONS}

Slope stability calculations have shown that the rainfall threshold values are a function of many variables, primarily the hydraulic properties of slope covers and rock substrate, temporal distribution of precipitation, and soil moisture content conditions (degree of slope cover saturation).

Permeable deposits have been shown to respond more readily to rainfall. In turn, in the case of less permeable deposits, the rainfall duration, which causes slow saturation of soils, plays an essential role.

The amount of rainfall that causes slope failure is significantly influenced by the prevalent moisture content conditions of the slope soil in the period preceding rainfall. Calculations indicate that, in extreme cases, accumulated rainfall threshold values for the same slope can range from $\sim 100$ to $500 \mathrm{~mm}$.

Calculated rainfall threshold values, represented by the rainfall intensity-duration threshold, were compared with extreme rainfall values noted in the Polish Flysch Carpathians and in other regions in the world. Comparison of those data showed estimated rainfall threshold values lower than those reported in the literature for Polish Carpathians. These differences may be associated with different methods of interpretation of the rainfall threshold values. However, the calculated rainfall threshold values are similar to those determined for Central and Southern Europe by Guzetti et al. (2007).

Acknowledgements. We thank anonymous reviewers for critical comments and suggestions which enabled us to improve the manuscript. 

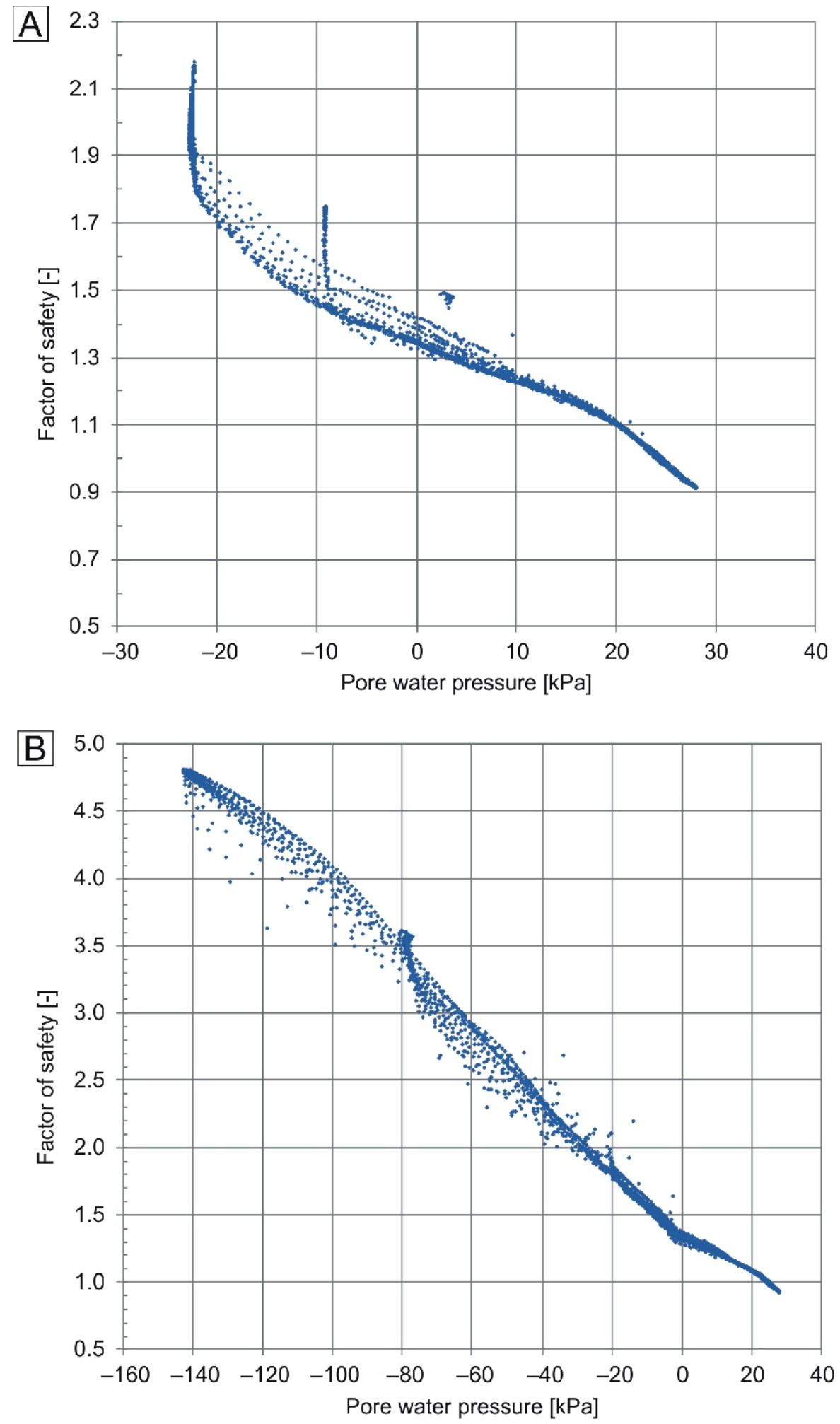

Fig. 11. Correlation between the factor of safety for the Dział (A) and Gwoździec (B) slopes and pore water pressure values 


\section{REFERENCES}

Aleotti, P., 2004. A warning system for rainfall-induced shallow failures. Engineering Geology, 73: 247-265.

Alexandrowicz, S. W., 1991. Molluscan fauna the Upper Vistulian and Holocene of the Cracow Upland (in Polish with English summary). Przegląd Geologiczny, 39: 257-262.

Bajgier, M., 1993. The role of geological structure in relief evolution on the eastern slopes of the Silesian Beskid and in the western part of Żywiec Basin (in Polish with English summary). Kwartalnik AGH, Geologia, 19: 1-69.

Baum, L.R., Coe, J.A., Godt, J.W., Harp, E.L., Reid, M.E., Savage, W.Z., Schulz, W.H., Brien, D.L., Chleborad, A.F., Mckenna, J.P., Michael, J.A., 2005. Regional landslide-hazard assessment for Seattle, Washington, USA. Landslides, 2: 266-279.

Bednarczyk, Z., 2010. Mechatronic system of landslide monitoring and warning (in Polish with English summary). Górnictwo Odkrywkowe, 51: 9-17.

Bednarczyk, Z., 2018. Identification of flysch landslide triggers using conventional and 'nearly real-time' monitoring methods - an example from the Carpathian Mountains, Poland. Engineering Geology, 244: 41-56.

Berti, M., Martina, M.L.V., Franceschini, S., Pignone, S., Simoni, A., Pizziolo, M., 2012. Probabilistic rainfall thresholds for landslide occurrence using a Bayesian approach. Journal of Geophysical Research, 117, F04006, doi:10.1029/2012JF002367

Bodziony, K., Baziak, B., 2007. Heavy rain effects on the example of 1997 and 2005 floods in the Wielka Puszcza Basin (in Polish with English summary). Czasopismo Techniczne, 2 Środowisko: $13-28$.

Boratyn, J., Bąk, M., Kasina, K., 2009. Mapa osuwisk i terenów zagrożonych ruchami masowymi w skali 1:10 000, gmina Raciechowice, powiat myślenicki, województwo małopolskie (in Polish) (M3477AD4).

Brunetti, M.T., Peruccacci, S., Rossi, M., Luciani, S., Valigi, D., Guzzetti, F., 2010. Rainfall thresholds for the possible occurrence of landslides in Italy. Natural Hazards Earth System Sciences, 10: 447-458.

Bucała, A., 2009. The role of shortlived downpours in shaping slopes and valley bottoms in the Gorce Mountains (as exemplified by the Jaszcze and Jamne catchments (in Polish with English summary). Przegląd Geograficzny, 81: 399-418.

Bucała, A., 2012. Contemporary environmental changes under human impact in the Jaszcze and Jamne stream valleys (the Gorce Mountains) (in Polish with English summary). Prace Geograficzne, 231: 1-146.

Burtan, J. 1954. Szczegółowa Mapa Geologiczna Polski w skali 1:5000, arkusz Wieliczka (in Polish). Państwowy Instytut Geologiczny.

Caine, L., 1980. The rainfall intensity-duration control of shallow landslides and debris flows. Geografiska Annaler, Series A, Physical Geography, 62: 23-27.

Cancelli, A., Nova, R., 1985. Landslides in soil debris cover triggered by rainstorms in Valtellina (central Alps - Italy). In: Proceedings 4th International Conference and FieldWorkshop on Landslides, Tokyo: 267-272. The Japan Geological Society.

Cannon, S.H., Ellen, S.D., 1985. Rainfall conditions for abundant debris avalanches, San Francisco Bay region, California. California Geology, 38: 267-272.

Cebulak, E., 1992. Maximum daily precipitation in the Upper Vistula basin (in Polish with English summary). Zeszyty Naukowe Uniwersytetu Jagiellońskiego, Prace Geograficzne, 1042: 79-96.

Cebulak, E., 1994. Variability of maximum daily precipitation in Upper Vistula basin. Wiadomości Instytutu Meteorologii i Gospodarki Wodnej, 17: 83-91.

Cebulska, M., Twardosz, R., 2012. Temporal variability of maximum monthly precipitation totals in the Polish Western
Carpathian Mts during the period 1951-2005 (in Polish with English summary). Prace Geograficzne, 128: 123-134.

Ceriani, M., Lauzi, S., Padovan, N., 1992. Rainfalls and landslides in the Alpine area of Lombardia Region, Central Alps, Italy. In: Proceedings of the Internantional Symposium "Interpraevent", 2: 9-20.

Clarizia, M, Gulla, G, Sorbino, G. 1996. Sui meccanismi di innesco dei soil slip. In: International Conferece Prevention of Hydrogeological Hazards: The Role of Scientific Research (ed. F. Luino), 1: 585-597. Alba, L'Artistica Savigliano.

Corominas, J., Ayala, F.J., Cendrero, A., Chacon, J., DI'az de Tera'n, J.R., Gonza'les, A., Moja, J., Vilaplana, J.M., 2005. Impacts on natural hazard of climatic origin. In: ECCE Final Report: A Preliminary Assessment of the Impacts in Spain due to the Effects of Climate Change. Ministerio de Medio Ambiente.

Crosta, G.B., Frattini, P., 2001. Rainfall thresholds for triggering soil slips and debris flow. In: Proceedings of 2nd EGS Plinius Conference on Mediterranean Storms (eds. A. Mugnai, F. Guzzetti and G. Roth): 463-487. GNDCI Publ., Siena.

Crosta, G.B., Frattini, P., 2003. Distributed modelling of shallow landslides triggered by intense rainfall. Natural Hazards and Earth System Sciences, 3: 81-93.

Czarnecka, M., Nidzgorska-Lencewicz, J., 2012. Multiannual variability of seasonal precipitation in Poland (in Polish with English summary). Woda-Srodowisko-Obszary Wiejskie, 12: 45-60.

Długosz, M., 2009. Landslide susceptibility zoning in the Polish Flysch Carpathians. Zeitschrift für Geomorphologie, Supplementary Issues, 53: 49-56.

Długosz, M., 2011. The role of extreme falls of rain in the transformation of Carpathian relief (a case study from Poland's Podhale region, June 2009) (in Polish with English summary). Przegląd Geograficzny, 83: 51-68.

Floris, M., Bozzano, F., 2008. Evaluation of landslide reactivation: A modified rainfall threshold model based on historical records of rainfall and landslides. Geomorphology, 94: 40-57.

Floris, M., Mari, M., Romeo, R.W., Gori, U., 2004. Modelling of landslide-triggering factors - a case study in the Northern Apennines, Italy.Lecture Notes in Earth Sciences, 104: 745-753.

Floris, M., Alpaos, A.D., De Agostini, A., Stevan, G., Tessari, G., Genevois, R., 2012. A process-based model for the definition of hydrological alert systems in landslide risk mitigation. Natural Hazards and Earth System Sciences, 12: 3343-3357.

Gerlach, T., Pokorny, J., Wolnik, R., 1958. Landslide in Lipowica (in Polish with English summary). Przegląd Geograficzny, 30: 685-700.

German, K., 1998. Przebieg wezbrania powodzi 9 lipca 1997 roku w okolicach Żegociny oraz ich skutki w krajobrazie (in Polish). In: Powódź w dorzeczu górnej Wisły w lipcu 1997 roku (eds. L. Starkel and J. Grela). Konferencja Naukowa, Kraków 7-9 May 1998: 177-184.

German, K., 2000. Functioning of flysch geosystems in a vicinity of Żegocina under extreme precipitation-flood conditions of 9 July 1997 (in Polish with English summary). Prace Geograficzne, 105: 235-256.

Giannecchini, R., 2005. Rainfall triggering soil slips in the southern Apuane Alps (Tuscany, Italy). Advances in Geosciences, 2: 21-24.

Giannecchini, R., Galanti, Y., D'Amato Avanzi, G., 2012. Critical rainfall thresholds for triggering shallow landslides in the Serchio River Valley (Tuscany, Italy). Natural Hazards and Earth System Sciences, 12: 829-842.

Gil, E., 1997. Meteorological and hydrological conditions of landslides in the Polish Flysch Carpathians. Studia Geomorphologica Carpatho-Balcanica, 31: 143-158. 
Gil, E., Długosz, M., 2006. Threshold values of rainfalls triggering selected deep-seated landslides in the Polish Flysch Carpathians. Studia Geomorphologica Carpatho-Balcanica, 40: 21-43.

Glade, T., Crozier, M., Smith, P., 2000. Applying probability determination to refine landslide-triggering threshold using an Empirical "Antecedent Daily Rainfall Model". Pure and Applied Geophysics, 157: 1059-1079.

Godt, J.W., Baum, R.L., Chleborad, A.F., 2006. Rainfall characteristics for shallow landsliding in Seattle, Washington, USA. Earth Surface Processes and Landforms, 31: 97-110.

Gorczyca, E., 2000. Role of mass movements in the slope modelling following a heavy rainfall in the Beskid Wyspowy Mountains (Flysch Carpathians Mountains). Landslides in Research, Theory and Practice: 653-658. Thomas Telford, Cardiff.

Gorczyca, E., 2002. Impact of heavy rainfall on the transformation of slopes on the example of the Łososina river basin (Beskid Wyspowy) (in Polish with English summary). Acta Universitatis Nicolai Copernici, Geografia, 32.

Gorczyca, E., 2004. Transformation of flysch slopes by mass processes during catastrophic rainfall (Łososina basin) (in Polish). Wydawnictwo Uniwersytetu Jagiellońskiego, Kraków.

Gorczyca, E., 2008. The geomorphological effectiveness of extreme meteorological phenomena on flysch slopes. Landform Analysis, 6: 17-27.

Guzzetti, F., Peruccacci, S., Rossi, M., Stark, C.P., 2007. Rainfal thresholds for the initiation of landslides in central and southern Europe. Meteorology and Atmospheric Physics, 98: 239-267.

Guzzetti, E., Peruccacci, S., Rossi, M., Stark, C.P. 2008. The rainfall intensity-duration control of shallow landslides and debris flows: an update. Landslides, 5: 3-17.

Hurlimann, M., Rickenmann, D., Graf, C. 2003. Field and monitoring data of debris-flow events in the Swiss Alps. Canadian Geotechnical Journal, 40: 161-175.

Jakubowski, K., 1964. Płytkie osuwiska zwietrzelinowe na Podhalu (in Polish). Prace Muzeum Ziemi, 6: 113-152.

Jakubowski, K., 1968. The role of shallow landslide weathered movements in slope processes in eastern Podhale (in Polish with English summary). Prace Muzeum Ziemi, 13: 173-314.

Jurys, L., Woźniak, T., Małka, A., Rudeńska, W., Frydel, J., 2011 Mapa osuwisk i terenów zagrożonych ruchami masowymi w skali 1:10 000, gmina Zakliczyn, powiat tarnowski, województwo małopolskie (in Polish) (M3478BC1, M3478BC2).

Kleczkowski, A., 1955. Osuwiska i zjawiska pokrewne (in Polish) Wyd. Geol., Warszawa.

Klimaszewski, M., 1935. Morfologiczne skutki powodzi w Małopolsce Zachodniej w lipcu 1934 r. (in Polish). Czasopismo Geograficzne, 13: 3-4.

Klimaszewski, M., 1972. Geomorfologia Polski (in Polish), T. 1 PWN.

Kondracki, J., 2009. Geografia regionalna Polski (in Polish). PWN.

Kotarba, A., 1986. Rola osuwisk w modelowaniu rzeźby beskidzkiej i pogórskiej (in Polish). Przegląd Geograficzny, 58: 119-129.

Lach, J., 2004. Results of flood of July 2001 in the Nowy Sącz district (in Polish with English summary). Folia Geographica ser. Geographica-Physica, 35-36: 77-91.

Lach, J., Lewik, P., 2002. Powódź w lipcu 2001 roku na Sądecczyźnie i jej skutki (in Polish). In: Geograficzne uwarunkowania rozwoju Małopolski (eds. Z. Górka and A. Jelonek): 199-204. Instytut Geografii UJ, Kraków.

Margielewski, W., 1994. Typy sukcesji ruchów masowych na przykladzie osuwisk pasma Jaworzyny Krynickiej (in Polish). Sprawozdanie z Czynności i Posiedzeń PAU, Kraków, 58: 110-114.

Margielewski, W., 2002. Geological control on the rocky landslides in the Polish Flysch Carpathians. Folia Quaternaria, 73: 53-68.

Maruszczak, H., 1985. Main genetic features and relief of loess covers in southern Poland. In: Guide-book of the International Sym- posium „Problems of the stratigraphy and paleogeography of loesses": 9-37. UMCS, Lublin.

Maruszczak, H., 1991. Ogólna charakterystyka lessów w Polsce (in Polish). In: Podstawowe profile lessów w Polsce (ed. H. Maruszczak), A: 1-12. UMCS, Lublin

Moser, M., Hohensinn, F., 1983. Geotechnical aspects of soil slips in Alpine regions. Engineering Geology 19: 185-211.

Oszczypko, N., Ślączka, A., Żytko, K., 2008. Tectonic regionalization of Poland - Outer Carpathians and the Carpathian Foredeep (in Polish with English summary). Przegląd Geologiczny, 56: 927-935.

Otop, I., 2004. Maksymalne dobowe opady atmosferyczne w Karkonoszach w drugiej połowie XX wieku (in Polish). Opera Corcontica, 41: 25-29.

Pack, R.T., Tarboton, D.G., Goodwin, C.N., 1999. GIS-based landslide susceptibility mapping with SINMAP. In: Proceedings of the 34th Symposium on Engineering Geology and Geotechnical Engineering (ed. J.A. Bay), Logan, Utah.

PN-EN ISO 14688-2. Geotechnical investigation and testing indentification and classification of soil - Part 2 - Principles for a classification. European Committee for Standardization.

Poprawa, D., Rączkowski, W., 1998. Geologiczne skutki powodzi 1997 na przykładzie osuwisk województwa nowosądeckiego (in Polish). In: Powódź w dorzeczu górnej Wisły (eds. L. Starkel and J. Grela): 119-131. Wydawnictwo PAN, Kraków.

Poprawa, D., Rączkowski, W., 2003. Carpathian land slides (southern Poland) (in Polish with English summary). Przegląd Geologiczny, 51: 685-692.

Rahardjo, H., Ong, T.H., Rezaur, R.B., Leong, E.C., 2007. Factors controlling instability of homogeneous soils slopes under rainfall. Journal of Geotechnical and Geoenvironmental Engineering, 133: 1532-1543.

Rahardjo, H., Satyanaga, A., Leong, E.C., Song, N.Y., 2010. Effects of groundwater table position and soil properties on stability of slope during rainfall. Journal of Geotechnical and Geoenvironmental Engineering, 136: 1555-1564.

Rahimi, A., Rahardjo, H., Leong, E.-C., 2011. Effect of antecedent rainfall patterns on rainfall-induced slope failure. Journal of Geotechnical and Geoenvironmental Engineering, 137: 483-491.

Rączkowski, W., Mrozek, T., 2002. Activiting of landsliding in the Polish Flysch Carpathians by the end of the 20th century. Studia Geomorphologica Carpatho-Balcanica, 36: 91-111.

Sawicki, L., 1917. Osuwisko ziemne w Szymbarku i inne zsuwy powstałe w roku 1913 w Galicyi zachodniej. (in Polish). Rozprawy Wydz. Mat.-Przyr. AU w Krakowie, 56, seria A, Kraków.

Schenk, V., Schenková, Z., Kottnauer, P., Guterch, B., Labák, P., 2001. Earthquake hazards maps for the Czech Republic, Poland and Slovakia. Acta Geophisica Polonica, 49: 287-302.

Skoczylas-Ciszewska, K., Burtan, J., 1954. Szczegółowa mapa geologiczna Polski w skali 1:50 000, arkusz Bochnia (in Polish). Państwowy Instytut Geologiczny.

Starkel, L., 1960. The development of the Flysch Carpathians relief during the Holocene (in Polish with English summary). Prace Geograficzne, 22.

Starkel, L., 1972. Karpaty Zewnętrzne, Geomorfologia Polski (in Polish), T. 1 . PWN.

Starkel, L., 2006. Geomorphic hazards in the Polish Flysch Carpathians. Studia Geomorphologica Carpatho-Balcanica, 40: 7-19.

Starkel, L., 2011. Temporal and spatial complexity of extreme rainfalls - their geomorphological effects and ways of counteract them (in Polish with English summary). Landform Analysis, 15: 65-80.

Tsai, T.-L., 2008. The influence of rainstorm pattern on shallow landslide. Environmental Geology, 53: 1563-1569. 
Tsai, T.-L., Wang, J.-K., 2011. Examination of influences of rainfall patterns on shallow landslides due to dissipation of matric suction. Environmental and Earth Sciences, 63: 65-75.

Tsai, T.-L., Chen, H.-E., Yang, J.-Ch., 2008. Numerical modeling of rainstorm-induced shallow landslides in saturated and unsaturated soils. Environmental Geology, 55: 1269-1277.

Ukleja, J., 2016. Stability estimation of slopes having their slip surface determined by means of the STAB-3D method based on sliding body equilibrium analysis. Geological Quarterly, 60 (3): 597-609.

Vaz, T., Zezere, J.L., Pereira, S., Oliveira, S.C., Garcia, R.A.C., Quaresma, I., 2018. Regional rainfall thresholds for landslide occurrence using a centenary database. Natural Hazards and Earth System Sciences, 18: 1037-1054.

Wieczorek, G.F., 1987. Effect of rainfall intensity and duration on debris flows in central Santa Cruz Mountains, California. GSA, Reviews in Engineering Geology, 7: 93-104.

Woźniak, A., 2011. Precipitation in the Polish Carpathian Mountains in 2010 compared to the period 1881-2010 (in Polish with English summary). Prace Geograficzne, 133: 35-48.

Wysokiński, L., 2011. The methods of landslides prediction and their protection (in Polish with English summary). XXV
Konferencja Naukowo-Techniczna Awarie Budowlane 2011, Międzyzdroje 24-27.05.2011: 291-320.

Zabuski, L., Wójcik, A., Gil, E., Mrozek, T., Raczkowski, W., 2009 Landslide processes in a flysch massif - case study of the Kawiory landslide, Beskid Niski Mts. (Carpathians, Poland). Geological Quarterly, 53 (3): 317-332.

Zasoński, S., 1981. Główne kierunki glebotwórcze na utworach pyłowych Pogórza Wielickiego. Część I. Ogólna charakterystyka gleb i niektóre właściwości chemiczne (in Polish). Roczniki Gleboznawcze, 32: 115-143.

Zezere, J.L., Trigo, R.M., Trigo, I.F., 2005. Shallow and deep landslides induced by rainfall in the Lisbon region (Portugal): assessment of relationships with the North Atlantic Oscillation. Natural Hazards and Earth System, Sciences, 5: 331-344.

Ziętara, T., 1969. W sprawie klasyfikacji osuwisk w Beskidach Zachodnich (in Polish). Studia Geomorphologica CarpathoBalcanica, 3: 111-127.

Zizioli, D., Meisina, C., Valentino, R., Montrasio, L., 2013. Comparison between different approaches to modeling shallow landslide susceptibility: case history in Oltrepo Pavese, Northern Italy. Natural Hazards and Earth System Sciences, 13: 559-573. 